\title{
Bean Flower Thrips Megalurothrips usitatus (Bagnall) (Insecta: Thysanoptera: Thripidae) ${ }^{1}$
}

\author{
Rafia Khan, Dakshina Seal, and Rosan Adhikari²
}

The Featured Creatures collection provides in-depth profiles of insects, nematodes, arachnids and other organisms relevant to Florida. These profiles are intended for the use of interested laypersons with some knowledge of biology as well as academic audiences.

\section{Introduction}

Megalurothrips usitatus (Bagnall, 1913) is a small sized (3-4 $\mathrm{mm}$ ) (Figure 1) insect in the order Thysanoptera and family Thripidae. Megalurothrips usitatus is commonly known as bean flower thrips, oriental bean thrips, and Asian bean thrips. Meagalurothris usitatus is an important economic pest of legumes (Mound and Walker 1987, Palmer 1987). Megalothrips usitatus is reported to cause feeding injury in bean flowers in south China (Tang et al. 2015) and Florida (Soto-Adames 2020). Thrips infesting beans like Megalurothrips usitatus are commonly found in flowers, causing feeding injury and leading to crop loss.

\section{Synonymy}

Frankliniella nigricornis Schmutz, 1913

Frankliniella obscuricornis Schmutz, 1913

Frankliniella vitata Schmutz, 1913

Physothrips usitatus Bagnall, 1913

Physothrips cinctipennis Bagnall, 1916

Physothrips mjobergi Karny, 1920

Taeniothrips longistylus Karny, 1922

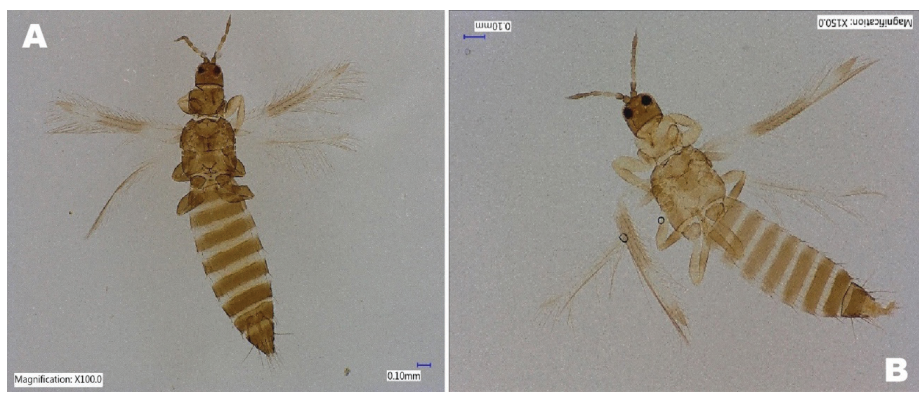

Figure 1. Adult female (A) and male (B) bean flower thrips, Meagalurothris usitatus Bagnall (dorsal view).

Credits: Rafia A. Khan, UF/IFAS Entomology and Nematology Department

\section{Distribution}

Megalurothrips usitatus is widely distributed in India, Bangladesh, Pakistan, Srilanka, the southern region of China, Japan, and Fiji (Tillekaratne et al. 2011, Tang et al. 2015). In Australia, Megalurothrips usitatus was reported in northern Australia, Western Australia to Queensland and north to New South Wales. Megalurothrips usitatus was first reported in the USA in Florida in 2020 (Soto-Adames, F. N. 2020).

\section{Description}

Megalurothrips usitatus adults are dark brown in color. Both male and female Megalurothrips usitatus are fully winged. The head is as wide as long, conspicuously transversely reticulate at posterior. The antenna is 8-segmented,

1. This document is EENY-777 one of a series of the Entomology and Nematology Department, UF/IFAS Extension. Original publication date October 2021. Visit the EDIS website at https://edis.ifas.ufl.edu for the currently supported version of this publication. This document is also available on the Featured Creatures website at http://entomology.ifas.ufl.edu/creatures.

2. Rafia Khan, UF/IFAS Tropical Research and Education Center; Dakshina Seal; and Rosan Adhikari; Entomology and Nematology Department, UF/IFAS Extension, Gainesville, FL 32611.

The Institute of Food and Agricultural Sciences (IFAS) is an Equal Opportunity Institution authorized to provide research, educational information and other services

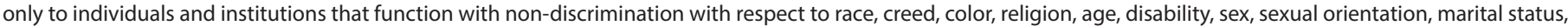

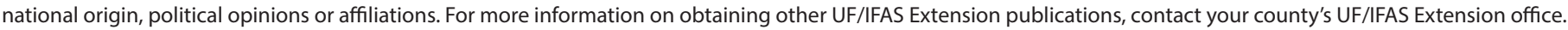
U.S. Department of Agriculture, UF/IFAS Extension Service, University of Florida, IFAS, Florida A \& M University Cooperative Extension Program, and Boards of County Commissioners Cooperating. Andra Johnson, dean for UF/IFAS Extension. 
antennal segments I-II brownish yellow, segment I with pair of dorso-apical setae, segment III yellow to light brown, and segment III-IV with constricted apical neck, sensorium forked (Figure 2).

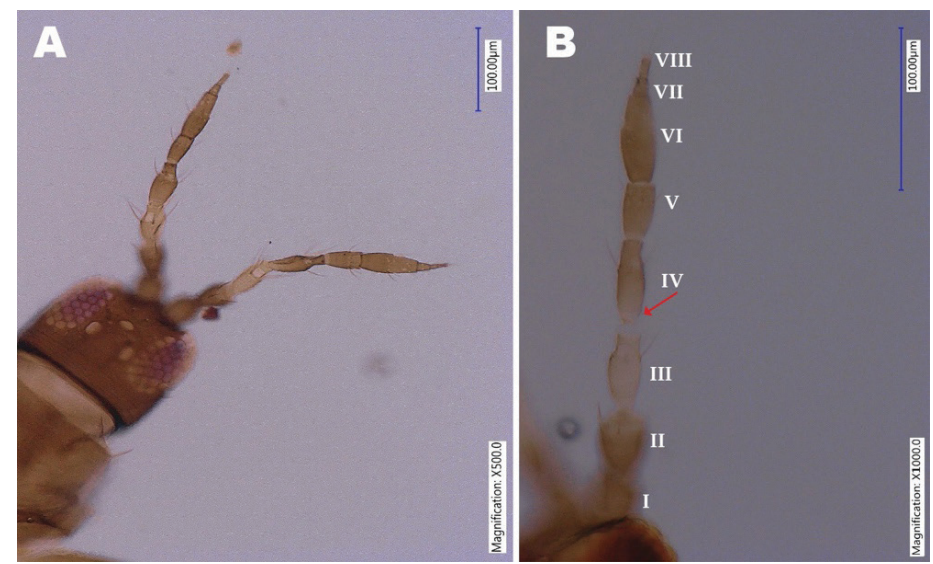

Figure 2. Head of an adult bean flower thrips, Meagalurothris usitatus Bagnall, showing antenna with eight antennal segments $(A)$ and enlarged view of one antenna (B) (arrow showing the constricted apical neck between segment III-IV).

Credits: Rafia A. Khan, UF/IFAS Entomology and Nematology

Department

Megalurothrips usitatus has three pairs of ocellar setae, pair III on anterior margins of ocellar triangle and longer than distance between compound eyes (Figure 3). The postocular setae are small.

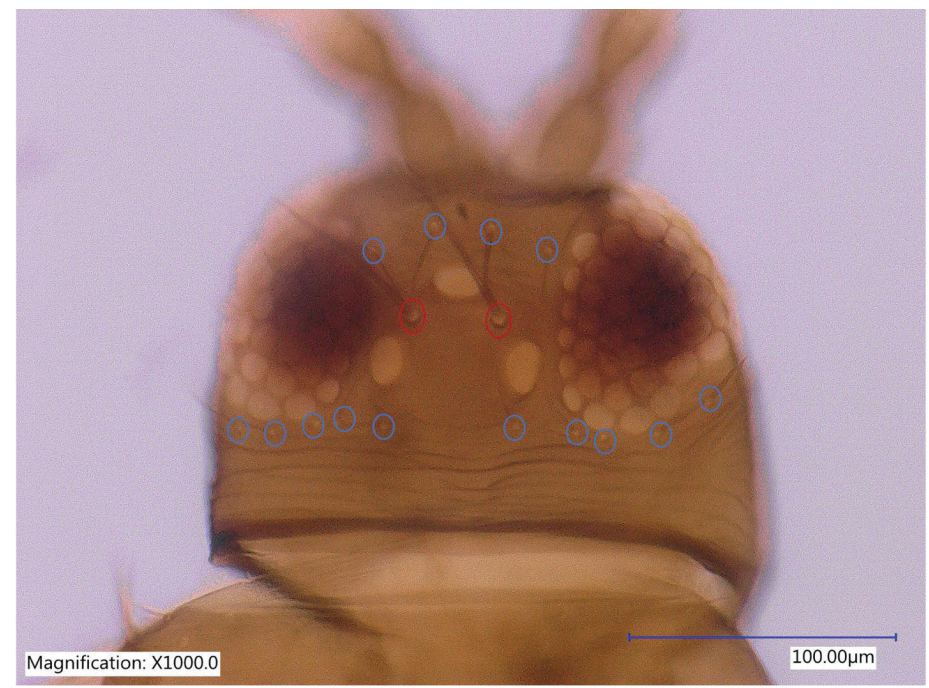

Figure 3. Head of an adult bean flower thrips, Meagalurothris usitatus Bagnall, showing ocelli and ocellar setae (Red circle).

Credits: Rafia A. Khan, UF/IFAS Entomology and Nematology

Department

The pronotum has two pairs of long posteroangular setae, outer longer than inner, posterior margin with three pairs of setae, anteroangular setae well developed (Figure 4). The mesonotum has transverse reticulation lateral setae. The metanotum has weak sculpture, campaniform sensilla present, median setae long, arise at anterior margin. All tarsi are two-segmented, apices of mid and hind tibiae and most part of fore tibia yellow, hind tibia with two stout dark apical setae.
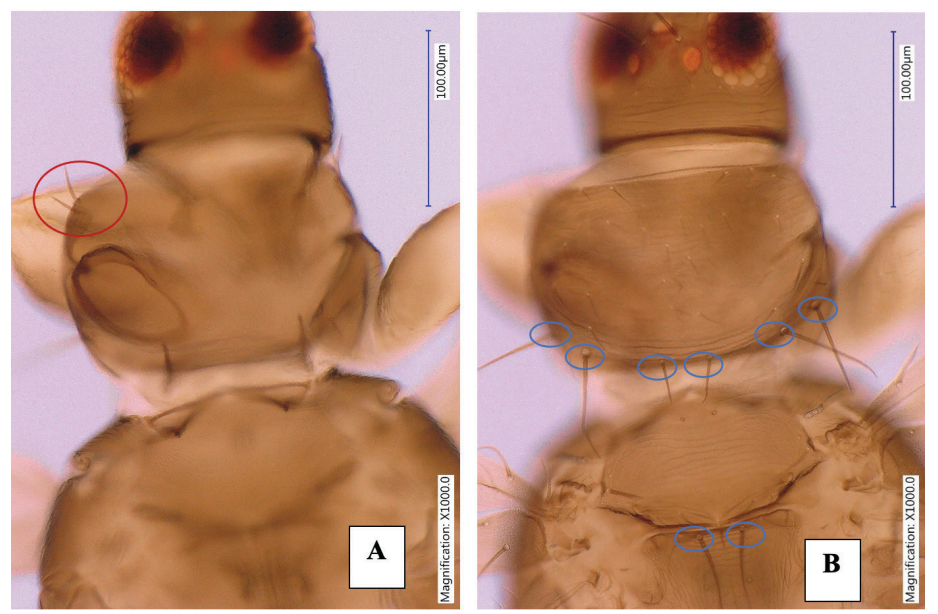

Figure 4. Head and thorax (Pro, meso and meta thorax) of an adult bean flower thrips, Megalurothrips usitatus Bagnall, showing (A) prothoracic (red circle) and (B) meta-thoracic setae (blue circle). Credits: Rafia A. Khan, UF/IFAS Entomology and Nematology Department

The fore wings are brown with basal quarter pale and an extensive pale area sub-apically. The first vein of fore wing has long row of setae before distinct sub-apical gap followed by 2 setae, and second vein has complete row of setae, postero-marginal cilia wavy (Figure 5).

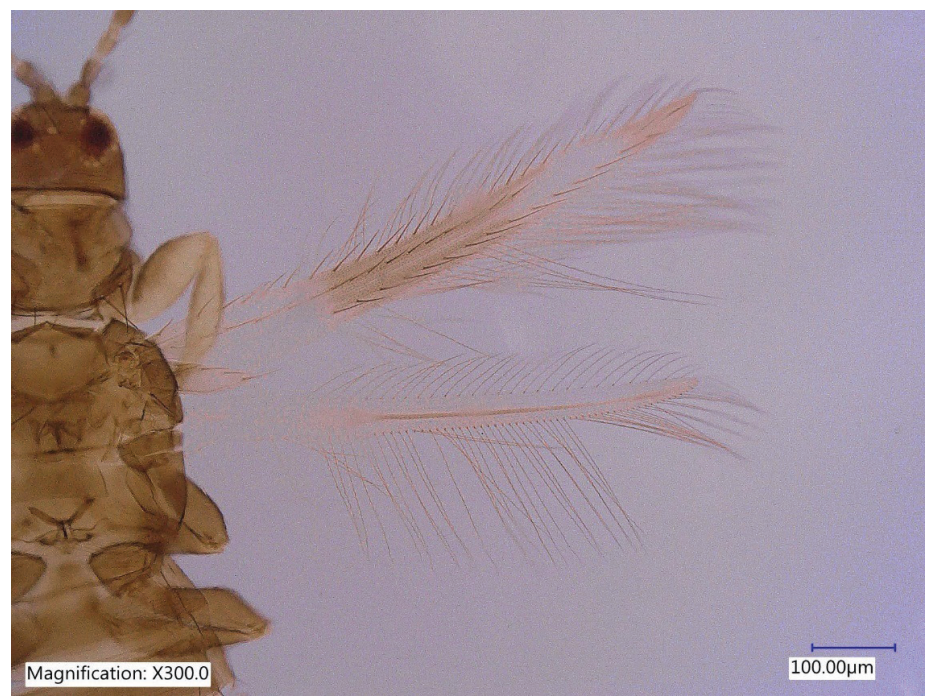

Figure 5. Wings of an adult bean flower thrips, Megalurothrips usitatus Bagnall.

Credits: Rafia A. Khan, UF/IFAS Entomology and Nematology Department

The abdominal tergites II-VIII are without sculpture medially, but lateral thirds with sub-parallel lines, median setae small, ctenidia absent. The VIII abdominal tergite has irregular group of microtrichia antero-mesad of spiracle, posteromarginal comb of slender microtrichia but broadly absent medially (Figures 6 and 7). The tergite $\mathrm{X}$ 
has incomplete longitudinal split. The sternites are without discal setae, three pairs of long marginal setae, median pair of marginal setae on sternite VII arise in front of margin.

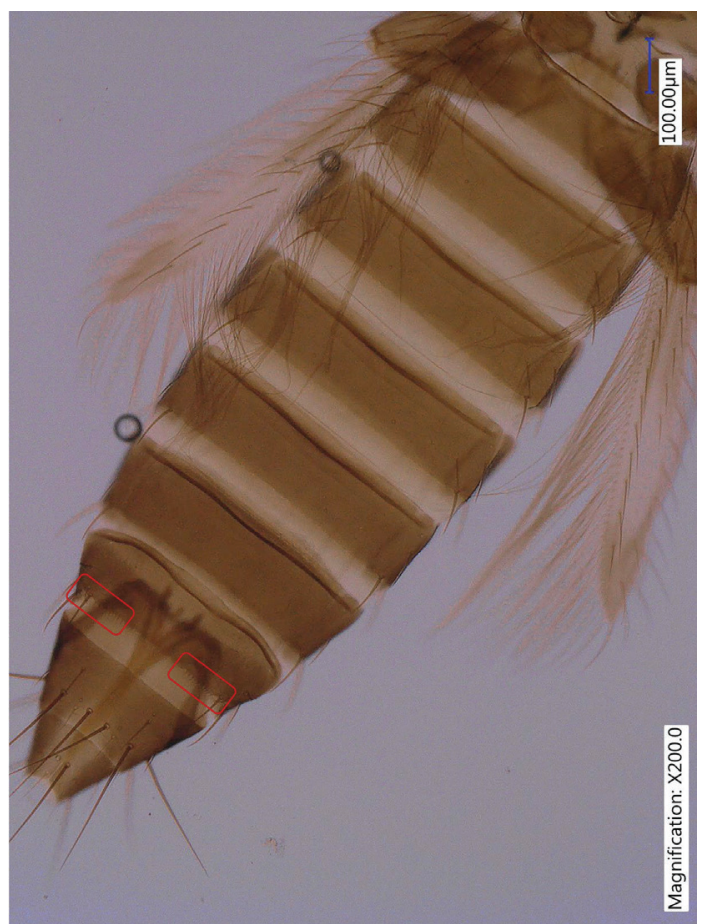

Figure 6. Abdominal tergite of female adult bean flower thrips, Megalurothrips usitatus Bagnall, showing incomplete comb at eighth abdominal segment.

Credits: Rafia A. Khan, UF/IFAS Entomology and Nematology Department
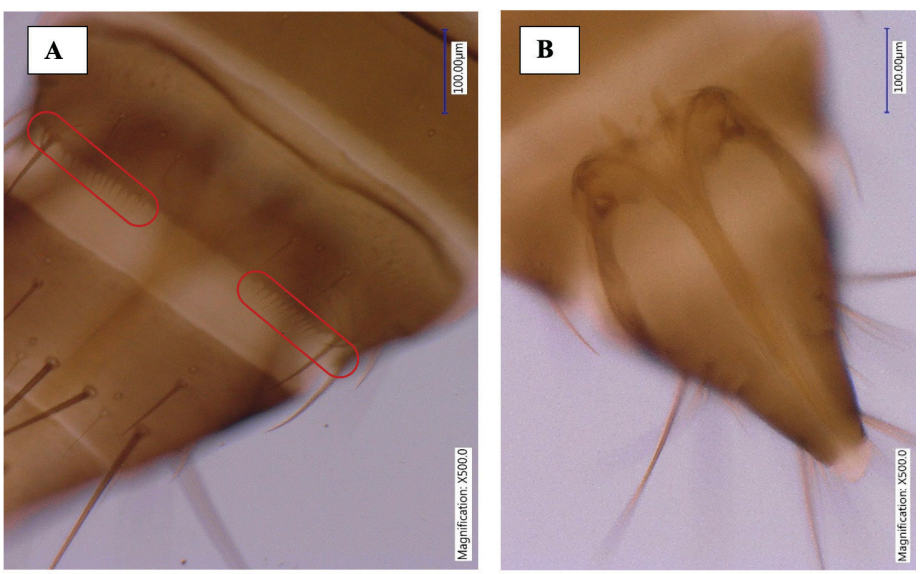

Figure 7. Abdominal tergites of a female adult composite thrips, Megalurothrips usitatus Bagnall, showing incomplete comb at eighth abdominal segment (A) and ovipositor (B).

Credits: Rafia A. Khan, UF/IFAS Entomology and Nematology Department

The male Megalurothrips usitatus is smaller and paler than the female. The pronotum and legs of the male Megalurothrips usitatus are yellow. The abdominal tergite IX posterior margin without paired setiform processes, posterolaterally with pair of short very stout setae, and sternites without pore plates (Figure 8).

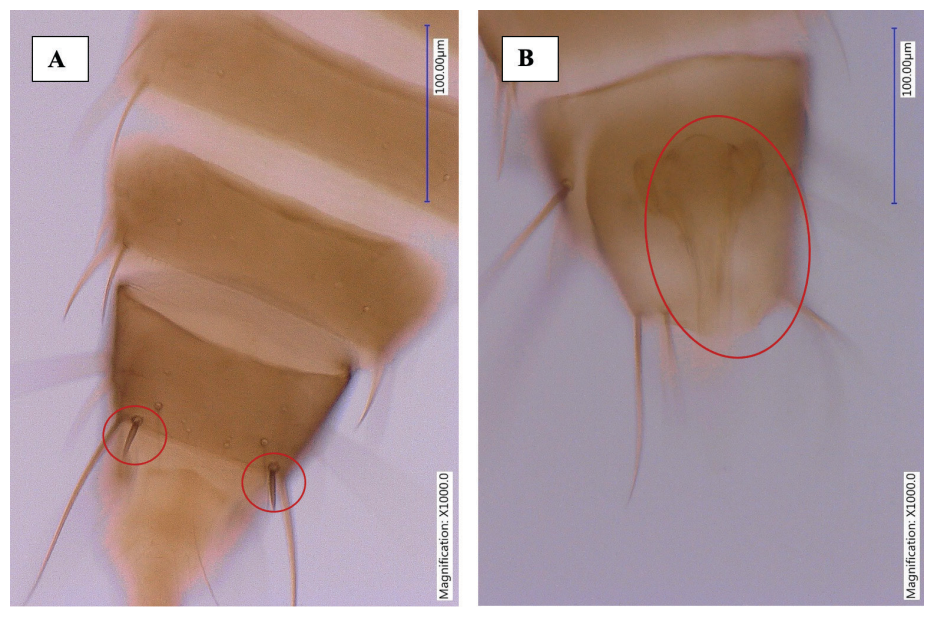

Figure 8. Abdominal tergites of male adult bean flower thrips, Megalurothrips usitatus Bagnall, showing abdominal tergite IX with pair of short and very stout setae (A) and copulatory organ (B). Credits: Rafia A. Khan, UF/IFAS Entomology and Nematology Department

Megalurothrips usitatus female is difficult to identify from several other related species (i. e. M. distatalis, M. formosae, M. mucunae and M. peculiaris). The male specimens of the species can provide the ultimate correct identification (Palmer 1987).

\section{Life Cycle and Biology}

The life stages of Megalurothrips usitatus include two larval instars, prepupa, pupa and adult. The early larval instars $\left(1^{\text {st }}\right.$ and $\left.2^{\text {nd }}\right)$ look white while the later stage of the $2^{\text {nd }}$ instar larva and prepupa look yellow to orange color. The developmental period from egg to adult depends on the host plants. Tang et al. (2015) reported Megalurothrips usitatus took $9.53 \pm 0.06,10.62 \pm 0.14,11.20 \pm 0.11$, and $11.55 \pm 1.13$ days to complete life cycle on snap bean (Phaseolus vulgaris L.), cowpea (Vigna unguiculata L.), pea (Pisum sativum L.) and lima bean (Phaseolus limensis Macf.) pods, respectively. The intrinsic rate of increase $\left(\mathrm{r}_{\mathrm{m}}\right)$ and net reproductive period $\left(\mathrm{R}_{\mathrm{O}}\right)$ of Megalurothrips usitatus was observed higher on snap bean compared to other beans. Megalurothrips usitatus can reproduce both sexually and parthenogenetically. Megalurothrips usitatus that reproduces parthenogenetically, lived longer and had longer oviposition periods and greater fecundity (Tang et al. 2015). With the increasing temperature, the developmental period of Megalurothrips usitatus was found to decrease. Megalurothrips usitatus was found dead after hatching above $30^{\circ} \mathrm{C}$ and below $14^{\circ} \mathrm{C}$. The most extended developmental period and higher fecundity were recorded at $20^{\circ} \mathrm{C}$ (Chang 1987). Greater mortality of larvae during pupation was observed in soil with low sand content and less than 2\% moisture content (Chang 1989). Adult Megalurothrips usitaus are mostly active between 8:00-10:00 am while being inactive at night. Megalurothrips 
usitatus exhibit aggregation behavior which is thought to be due to the male-produced aggregation pheromone (Liu et al. 2020). Megalurothrips usitatus male and females are found aggregated on the host and their numbers increased after the mid-blooming stage. The larval population was distributed randomly with low population and became contagious when the population increased (Chang 1992). The number of larvae peaked five to seven days later than the adult population (Chang 1988b). Tan et al. (2015) revealed that Megalurothrips usitatus preferred cowpea (Vigna unguiculata L.) leaves over common beans (Phaseolus vulgaris L.) and groundnut (Arachis hypogaea L.) leaves for oviposition. Both adults and larvae of Megalurothrips usitatus preferred the flowers to the leaves as found in a choice test on adzuki bean (Vigna angularis L.). When given a choice, adzuki bean was the most preferred bean to Megalurothrips usitatus, followed by groundnut and soybean (Glycine max L.) (Chang 1988a). In another study, Tan et al. (2015) found that the female Megalurothrips usitatus preferred the adaxial surfaces of young leaves over the abaxial surface. They also revealed that the cowpea leaves were the most favored oviposition site when given the choice of cowpea, common bean, and groundnut leaves. They observed the female Megalurothrips usitatus oviposited $85 \%$ of their eggs on young cowpea leaves.
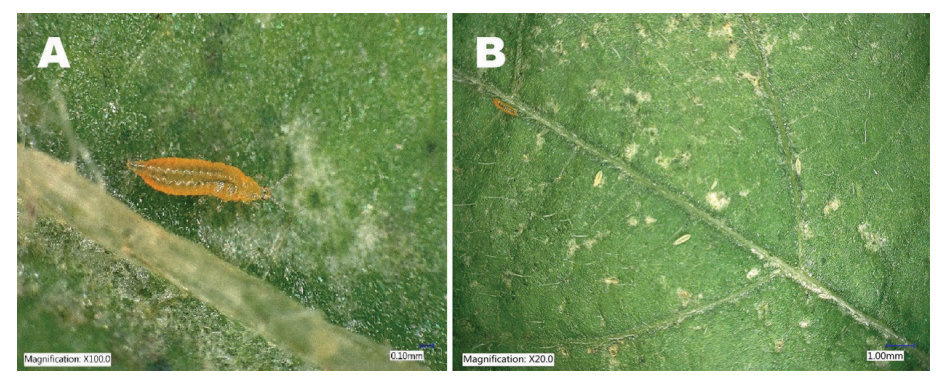

Figure 9. Immature stages of Megalurothrips usitatus Bangall, showing second larval instar (A), and first and second larval instars (B). Credits: Rafia A. Khan, UF/IFAS Entomology and Nematology Department
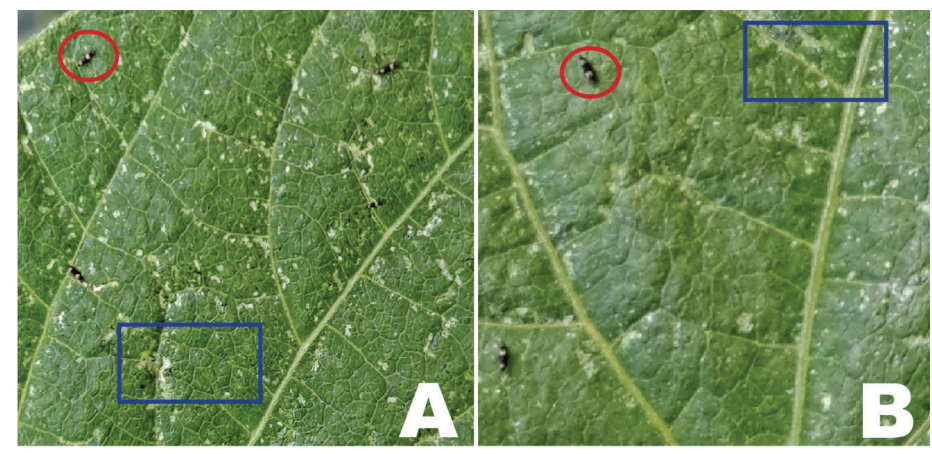

Figure 10. Adults of Megalurothrips usitatus Bangall (red circle), on bean leaf showing the feeding injury (blue rectangle) ( $A$ and $B$ ). Credits: Rafia A. Khan, UF/IFAS Entomology and Nematology Department

\section{Host Plants}

Megalurothrips usitatus was found on 28 plant species in nine families and 16 of the species belonged to the Leguminosae (Chang 1987). Various Leguminosae crops in the genus Glycine, Arachis, and Vigna are hosts of Megalurothrips usitatus. Important hosts of Megalurothrips usitatus includes mung bean (Vigna radiate (L.) R. Wilczek), snap bean (Phaseolus vulgaris L.), cowpea (Vigna unguiculata L., pea (Pisum sativum L.), lima bean (Phaseolus limensis Macf.), groundnuts (Arachis hypogaea L.), pigeon pea (Cajanus cajan L.), yard-long bean (Vigna unguiculata subsp. sesquipedalis L.), matura tea tree (Cassia auriculata L.), Calandine Spider Flower (Cleome chelidonii L.), sunn hemp (Cratalaria juncea L.), Caracas Rattlebox (Crotalaria micans L.), variable-leaf ticktrefoil (Desmodium heterophyllum DC.), Indian coral tree (Erythrina variegate L.), Mexican lilac (Gliricidia sepium Walp.), hiptage (Hiptage benghalensis L.), tropical kudzu (Pueraria phaseoloides Benth.), vegetable hummingbird (Sesbania grandiflora L.), black gram (Vigna mungo L.), and soybean (Glycine max L. Merr) (Fletcher 1917, Palmer 1987, Tillekarratne et al. 2011, Sani and Umar 2017, Tang et al. 2015, Zafirah and Azidah 2018).

\section{Economic Importance}

Megalurothrips usitatus, like other legume thrips, can cause an $80-100 \%$ yield reduction in legume crops (Oparaeke 2006). Both larvae and adults feed on flower buds. Megalurothrips are commonly associated with injury to bean crops through feeding in the flowers, resulting in deformity and abortion of pods. However, Megalurothrips usitatus can feed on young leaves and pods of leguminous when flowers are not available (Duff et al. 2014, Tang et al. 2015). In mung bean, Megalurothrips usitatus can cause $13 \%$ to $64 \%$ yield losses through several infestations (Farajallah 2013). It was also reported that the presence of 13 individuals of Megalurothrips usitatus on untreated pigeon pea caused $36 \%$ of pod reduction (Rawat et al. 1969). Megalurothrips usitatus is one of the vectors of Tobacco Streak Virus (TSV). Transmission of TSV occurs when Megalurothrips usitatus carries TSV infected pollen from the infected plants on their bodies and inoculates virus to the new host while feeding on plant tissue (Prassda Rao et al. 2003, Shukla et al. 2005). 


\section{Management}

\section{Sampling and Monitoring}

The sticky trap and water trap methods are effective methods for sampling Megalurothrips usitatus (Chang 1988b). Blue sticky traps are the most attractive to Megalurothrips usitatus (Yan et al. 2017). The male produced aggregation pheromone of Megalurothrips usitatus can be used to develop commercial lures to monitor the pest and mass trapping (Liu et al. 2020).

\section{Chemical Control}

Insecticides of different modes of action used in different regions of the world provided suppression of Megalurothrips usitatus. (Peter and Govindarajulu 1990, Hossain 2015, Sujatha and Bharpoda 2017, Yasmin et al. 2019, Maradi et al. 2020). Heavy application and frequent use of insecticides can have an adverse effect on the environment, humans and other living organisms as well as interrupting the biological balance between natural enemies and insect pests. There is a growing concern to develop environmentally friendly and biodegradable insecticides to manage Megalurothrips usitatus. Alternatives to conventional insecticides, such as neem seed powder, garlic, ginger, papaya, and ginger rhizome extracts were effective in suppressing the population and intensity of Megalurothrips usitatus attack on mung bean (Farajallah 2013, Srinivasan et al. 2019). However, these alternative bioproducts need to be fully evaluated.

\section{Biological Control}

The eulophid wasp, Ceranisus menes, was identified as a parasitoid of Megalurothrips usitatus in an adzuki bean field in Taiwan (Chang 1990) and in the Philippines (Loomans 2006). Minute pirate bug Orius maxidentex Ghuri (Hemiptera: Anthocoridae) is a natural predator used against Megalurothrips usitatus in India (Men 1999). Lee et al. (1991) found that Orius strigicollis (Poppius) effectively reduced the Megalurothrips usitatis on adzuki beans and sweet potatoes in Taiwan. In China, Orius sauteri (Poppius) is a significant predator of Megalurothrips usitatus. In a laboratory study, female and male Orius sauteri can consume an average of 304.7 and 104 thrips over their lifetimes, respectively (Liu et al. 2018). Microbial pathogens, Bacillus thuringiensis and Metarhizium anisopliae formulations effectively managed Megalurothrips usitatus population (Srinivasan et al. 2019). Entomopathogenic fungi, isolates of Akanthomyces attenuatus (SCAUDCL-38 and SCAUDCL-56), can cause $76.25 \%$ and $57.5 \%$ mortality of adult Megalurothrips usitatus after five days of treatment with $1 \times 10^{8}$ conidia/ml (Du et al. 2019).

\section{Cultural Control}

Heavy rainfall reduces the population of Megalurothrips usitaus on pigeon pea (Dialoke 2013). As Megalurothrips usitatus is a vector of TSV, tall border crops such as sorghum, pearl millet and castor can serve as a barrier for thrips coming from a nearby infected area (Prassda Rao et al. 2003). Avoiding planting next to the infested field, or next to a kudzu patch, rotating crops with non-host crops (non-legume plants), can break the lifecycle of Megalurothrips usitatus. Intercropping with a non-host plants like bell pepper (Capsicum sp. L.) between yard long beans can slow thrips movement through the crop. Before planting beans, the edge and surrounding areas around the bean fields should be properly sanitized to destroy wild hosts (Jackson 2017).

\section{Conclusion}

Beans, especially the snap bean (Phaseolus vulgaris L.), is an important crop of Florida. Miami-Dade and Palm Beach are two major snap bean-producing counties in Florida. Snap bean growers of Miami-Dade County encounter serious feeding damage from Megalurothrips usitatus, which is recently invaded in south Florida in the 2019-2020 growing season. Several snap bean fields were abandoned, and economic losses were enormous (20-50\%). Different bean varieties are also susceptible to the feeding injury of Megalurothrips usitatus. Megalurothrips usitatus appeared as the major thrips problem in south Florida and invading different Leguminosae crops grown here. Megalurothrips usitatus started to invade other counties in Florida during the short time of its establishment. Future study on the distribution, biology and management of Megalurothrips usitatus in south Florida is necessary to combat this invasive pest.

\section{Reference}

Chang NT. 1987. Seasonal abundance and developmental biology of thrips Megalurothrips usitatus on soybean at southern area of Taiwan. Plant Protection Bulletin Taiwan 29(2):165-173.

Chang NT. 1988a. The preference of thrips, Megalurothrips usitatus (Bagnall), for three leguminous plants. Plant Protection Bulletin Taiwan 30(1):68-77.

Chang NT. 1988b. Population trends of Megalurothrips usitatus (Bagnall) (Thysanoptera: Thripidae) on adzuki bean and soybean examined by four sampling methods. Plant Protection Bulletin Taiwan 30(3):289-302. 
Chang NT. 1989. Impacts of soil physical factors on the pupation of bean flower thrips, Megalurothrips usitatus (Bagnall) (Thysanoptera: Thripidae). Plant Protection Bulletin Taiwan 31(4):377-386.

Chang NT. 1990. Ceranisus menes (Walker) (Eulophidae: Hymenoptera), a new parasite of bean flower thrips, Megalurothrips usitatus (Bagnall) (Thripidae: Thysanoptera). Plant Protection Bulletin (Taipei) 32(3):237-238.

Chang NT. 1992. Dispersion patterns of bean flower thrips, Megalurothrips usitatus (Bagnall) (Thysanoptera: Thripidae) on flowers of adzuki bean. Plant Protection Bulletin (Taipei) 34(1):41-53.

Dialoke S. 2013. The Population of Leaf Beetles (Leptualaca fassicollis thoms Coleoptera: Chrysomelidae) and Flower Thrips (Megalurothrips usitatus Bagnall Thysanoptera: Thripide) on Pigeon pea under the influence of plant density and planting date in a Rain Forest Zone, Nigeria. Journal of Biology Agriculture and Healthcare 3(8):81-86.

Du C, Yang B, Wu J, Ali S. 2019. Identification and virulence characterization of two Akanthomyces attenuatus isolates against Megalurothrips usitatus (Thysanoptera: Thripidae). Insects 10(6):168.

Duff JD, Church CE, Healey MA, Senior, L. 2014. Thrips incidence in green beans and the degree of damage caused. In XXIX International Horticultural Congress on Horticulture: Sustaining Lives, Livelihoods and Landscapes (IHC2014): 1105 (pp. 19-26).

Farajallah A. 2013. Effect of chemical and botanical insecticides on thrips and yield of mung bean. Indonesian Journal of Agricultural Science 6(2):87-92.

Fletcher T. 1917. Leguminous field crops: pests of Cajanus indicus (red gram). Proceedings of the $2^{\text {nd }}$ Entomology meeting, Pusa pp 41-79.

Funderburk J. 2017. Oriental Bean Thrips: A Potential Threat to Florida Bean Crops. https://nwdistrict.ifas.ufl. edu/phag/2017/04/07/oriental-bean-thrips-a-potentialthreat-to-florida-bean-crops/

Hossain MA. 2015. Efficacy of some insecticides against insect pests of mung bean (Vigna radiata L.). Bangladesh Journal of Agricultural Research 40(4):657-667.
Jackson, G. 2017. Bean flower thrips (342). Pacific pests and pathogens fact sheets. https://www.pestnet.org/fact_sheets/ bean_flower_thrips_342.pdf

Lee C, Lin F, Lu C, Wang C. 1991. Natural enemies and their use in the biocontrol of insect pests in Taiwan. In Proceedings of International Seminar on Enhancement of Functional Biodiversity Relevant to Sustainable Food Production, Tsukuba, Japan. MARCO, Tsukuba, Japan.

Liu P, Jia W, Zheng X, Zhang L, Sangbaramou R, Tan S, Liu Y, Shi W. 2018. Predation functional response and life table parameters of Orius sauteri (Hemiptera: Anthocoridae) feeding on Megalurothrips usitatus (Thysanoptera: Thripidae). Florida Entomologist 101(2):254-259.

Liu P, Qin Z, Feng M, Zhang L, Huang X, Shi W. 2020. The male-produced aggregation pheromone of the bean flower thrips Megalurothrips usitatus in China: identification and attraction of conspecifics in the laboratory and field. Pest Management Science 76:2986-2993.

Loomans AJ. 2006. Exploration for hymenopterous parasitoids of thrips. Bulletin of Insectology 59(2):69-83.

Maradi RM, Rajashekharappa K, Pradhan K. 2020. Evaluation of bio-efficacy of newer molecules of insecticides against thrips, Megalurothrips usitatus in yard long bean, Vigna unguicula, subsp. sesquipedalis. The Bioscan 15(2):189-192.

Men UB. 1999. Orius maxidentex Ghauri as predator on sunflower thrips. Insect Environment 5(1):22-23.

Mound LA, Walker AK. 1987. Thysanoptera as tropical tramps: new records from New Zealand and the Pacific. New Zealand Entomologist 9:70-85.

Oparaeke AM. 2006. The sensitivity of flower bud thrips, Megalurothrips sjostedti Trybom (Thysanoptera: Thripidae), on cowpea to three concentrations and spraying schedules of Piper guineense Schum. \& Thonn. extracts. Plant protection science 42(3):106-111.

Palmer J. 1987. Magalurothrips in the flowers of tropical legumes: a morphometric study. In Holman J, Pelican J, Dixon AFG, Weismann L. (eds.), Population Structure, Genetics and Taxonomy of Aphids and Thysanoptera: SPB Academic Publishing, Amsterdam, The Netherlands, pp. 480-495. 
Peter C, Govindarajulu V. 1990. Management of blossom thrips, Megalurothrips usitatus on pigeon pea. International Journal of Pest Management 36(3):312-313.

Prasada Rao RDVJ, Reddy AS, Reddy SV, Thirumala-Devi K, Rao SC, Manoj Kumar V, Subramaniam K, Reddy TY, Nigam SN, Reddy DVR. 2003. The host range of Tobacco streak virus in India and transmission by thrips. Annals of Applied Biology 142 (3):365-368.

Rawat RR, Singh Z, Jakhmola SS. 1969. Effect of infestation of blossom-thrips on pod setting in pigeon-pea, Cajanus cajan (L.) Millsp. Indian Journal of Agricultural Sciences 39(7):623-625.

Sani I, Umar KM. 2017. Biology and management of legume flower thrips (Megalurothrips sjostedti) (Thysanoptera: Thripidae), a major insect pest of cowpea: A Review. Annals of Experimental Biology 5(1):14-17.

Shukla S, Kalyani G, Kulkarni N, Waliyar F, Nigam SN. 2005. Mechanism of transmission of Tobacco streak virus by Scirtothrips dorsalis, Frankliniella schultzei and Megalurothrips usitatus in groundnut, Arachis hypogaea L. Journal of Oilseeds Research 22:215-217.

Soto-Adames FN2020. Megalurothrips usitatus (Bagnall), Asian bean thrips, Oriental bean flower thrips or bean flower thrips. Pest Alert. Florida Department of Agriculture and Consumer Services Division of Plant Industry. FDACSP-02137. Bureau of Entomology, Nematology and Plant Pathology.

Srinivasan R, Paola s, LinMY, Hy HC, Sareth K, Sor S. 2019. Development and validation of an integrated pest management strategy for the control of major insect pests on yard-long bean in Cambodia. Crop Protection 116:82-91.

Sujatha B, Bharpoda TM. 2017. Evaluation of insecticides against sucking pests grown during Kharif. International Journal of Current Microbiology and Applied Sciences 6(10): 1258-1268.

Tan K, Li M, Chen X, Ge W, Dan J. 2015. Preliminary studies on oviposition preference of bean flower thrips, Megalurothrips usitatus (Bangall). Chinese Journal of Tropical Crops 36(3):587-590.

Tang LD, Yan KL, Fu BL, Wu JH, Liu K, Lu YY. 2015. The life table parameters of Megalurothrips usitatus (Thysanoptera: Thripidae) on four leguminous crops. Florida Entomologist 98(2):620-625.
Tillekaratne K, Edirisinghe JP, Gunatilleke CVS, Karunaratne WAIP. 2011. Survey of thrips in Sri Lanka: A checklist of thrips species, their distribution and host plants. Ceylon Journal of Science (Biological Sciences) 40(2):89-108.

Yan K, Tang LD, Hui WJ. 2017. Color preferences and diurnal rhythm of Megalurothrips usitatus (Bagnall) (Thysanoptera: Thripidae). Chinese Journal of Applied Entomology 54(4): 639-645. DOI: 10.7679/j.issn.20951353.2017.078

Yasmin S, Latif MA, Ali M, MM Rahman. 2019. Management of thrips infesting mung bean using pesticides. SAARC Journal of Agriculture 17(2):43-52.

Zafirah Z, Azidah AA. 2018. Diversity and population of thrips species on legumes with special reference to Megalurothrips usitatus. Sains Malaysiana 47(3):433-439. 